\title{
Challenges to the nation-state in the context of European integration: an overview of the tension between citizenship rights and neoliberalism
}

\author{
Javier Martínez Contreras ${ }^{a}$, Daniela Nascimento ${ }^{b}$ and Licínia Simão ${ }^{b}$ \\ ${ }^{a}$ Department of International Relations and Humanities, Centre for Applied Ethics, Faculty of Social and \\ Human Sciences, University of Deusto, Bilbao, Bizkaia, Spain; ${ }^{\mathrm{b}}$ Faculty of Economics and Centre for Social \\ Studies, University of Coimbra, Coimbra, Portugal
}

\begin{abstract}
Neoliberalism has had a profound impact on the relations between the state and citizens, namely in the enjoyment of their rights. In the context of European integration, citizenship is conceptualised and practiced as a multi-level attribute, posing both challenges and opportunities, for its fulfilment. The article engages with this multilevel and multifaceted nature of citizenship in the European Union, reflecting the contested role of the nation-state in a globalised neoliberal context, as well as the consequences at the local and individual levels. The impacts on the exercise of citizenship in this context is a central concern of this article, focusing on how neoliberal globalisation has affected state-citizen relations, particularly in the context of European integration. As European integration faces a critical moment, European civil society has engaged in citizen-based organisations and movements seeking to challenge the limits of the existing political structures and demand a more participative role in society and politics.
\end{abstract}

\section{KEYWORDS}

Citizenship; nation-state; rights; European integration; neoliberalism; civil society

\section{Introduction}

The process of European integration is facing a critical moment, due mainly to three factors: the erosion of the nation state's territoriality and its sovereignty; its inability to manage global processes with local impacts; and the discredit of formal channels for political democratic action, at the local, national and regional levels, due to corruption, inefficiency and neglect of citizens' rights. As an expression of the conjugation of these factors, European politics is facing the challenges of populism, racism and xenophobia, which influence how citizenship is affirmed and enacted (Mackert \& Turner, 2017). As a response to these processes, European civil society - as in other parts of the world - has engaged with citizen-based organisations and movements seeking to challenge the limits of the existing political structures and demand a more participative role in both society and politics (Gerbaudo, 2017; Kohler-Koch, 2009). Citizenship becomes a central concept in this process, as it harnesses both the issue of rights and the role of the state. This poses two

CONTACT Daniela Nascimento danielan@fe.uc.pt E Faculty of Economics and Centre for Social Studies, University of Coimbra, Av. Dias da Silva 165, Coimbra 3004-512, Portugal 
fundamental challenges for European integration: one is the need for multilevel political action grounded on the respect for the rights citizenship considers as non-derogable; the second is the rethinking of the role of the state as a political actor and one who has the higher responsibility of promoting and fulfilling citizens' rights.

Considering this context, the article seeks to address the relations between citizenship, the state and European integration. The main research question guiding our reflection is to what extent neoliberal globalisation has affected state-citizen relations, particularly in the context of European integration? In order to respond to this question, the article engages with a multilevel and multifaceted analysis, reflecting the contested role of the nationstate in a globalised context, particularly regarding its relations with citizens and their rights. The article takes European integration as the empirical illustration of these challenges and analysis the emergence of European Citizenship as a tentative reconciliation of these dynamics.

\section{Neoliberal globalisation and the erosion of the political role of the nation-state}

The development of the so-called globalisation processes has fostered a debate about the role of the state as political institution and the new possibilities of citizenship. These processes seem to be the main factors feeding the visible changes affecting the political role and meaning of the nation-sate, including regarding its primary functions as a promotor and enactor of citizenship rights. The way we understand and effectively perform citizenship in the context of European integration is simultaneously affected by the evolving relations between states and EU institutions, and by global interdependence, which provokes very fast changes in its economic, social, political and cultural structures.

With different nuances, some of the most relevant analysts of these globalisation processes, namely Saskia Sassen (2015) , Wendy Brown (2010) or Boaventura de Sousa Santos (2006), agree in their assessment that one of its key features is the transformation of the meaning of the political role of the state. By shifting the meaning of one of the modern nation states' core features - sovereignty -, globalisation puts pressure on state-citizen relations and in the enactment of citizen rights. This is probably one of the most relevant and significant concepts of the political theory of modernity and is the foundation of the international political architecture we have known and recognised for the last two centuries. It is probably not relevant to examine thoroughly the different meanings and uses of this concept, but it is worth paying attention to some of the recent dynamics touching territoriality and the regulation of the economy to understand how the political role of the nation-state is being changed.

In Saskia Sassen's words (2015: xii), for example, '[a]n examination of a wide range of changes in terms of what a large firm operating internationally is now authorised to do and what a citizen could legitimately claim, made it clear that firms were gaining rights while citizens were losing theirs'. This assessment addresses one of the central developments of globalisation and stresses the main concern of this part of our reflections. In fact, the changes generated by the development of a certain type of global economic management in the last quarter of a century modified the meaning of territoriality, politics, and citizenship. 
According to Boaventura de Sousa Santos (2006), the core of the neoliberal model of globalisation (what he calls the 'hegemonic globalisation') entails different processes with different speeds and occurring at differentiated levels. Probably one of the most relevant issues affecting the economic process is the detachment between financial economy and the economy of production. This process has led to a new international division of labour but also to the implementation of a 'pro-market' political economy that has driven inter-state political agreements. In the case of the EU, these agreements involve a kind of shared sovereignty. In any case,

The nation state seems to have lost its traditional centrality as the favourite unit for economic, social and political initiatives. Intensified interactions across borders and transnational practices have eroded the ability of the nation-state to guide or even control the flows of people, goods, capital or ideas as it did in the past. (Sousa Santos, 2002)

Saskia Sassen $(2015)$ and Wendy Brown $(2010,2015)$ also converge on the recognition of the different regimes for the circulation of capital and of people. Moreover, Sassen (2015) also points out two different regimes for the protection of human rights and the protection of state sovereignty. The point in which political sovereignty and territoriality meet is the one related to the circulation of people and the protection of human rights, currently expressed by the phenomenon of migration. Yet, the purpose is to underline how these circulation regimes establish a critical political paradox, crystallised around the term 'deregulation'. This term is often used to refer to the decline of the state, stressing its inability to legislate and to enforce the fulfilment of law beyond its borders, or even creating internal zones with special legal status usually free from certain obligations (taxes, security at labour, environmental requirements, etc.). However, the so-called 'deregulation' also establishes a new legal order, a renewed configuration of space (since globalisation implies and demands a completely different management of territories) and, in doing so, erodes the traditional meaning of sovereignty. According to Sassen (2015, p. 27), deregulation is not simply a loss of control (which in fact relates to certain domains of the economy and therefore of politics), 'but a crucial mechanism for handling the juxtaposition of the interstate consensus to pursue globalisation and the fact that national legal systems remain as the major, or crucial, instantiation through which guarantees of contract and property rights are enforced'. The paradox is thus that, in appearance, deregulation claims for a weak state, whereas it hides a legal transformation towards a new (stronger) legal system for the sake of specific groups or corporative interests, subordinating the state to its care and protection.

The juxtaposition of regimes governing circulation of capital and people implies the de facto decentralisation of sovereignty (with positive and negative aspects, as we will see) and the denationalisation of territory. Both configure the weakness of the actual nationstates apart from the international legal regime developed since 1945 (Ferrajoli, 2010). There is a repeated consensus around the idea of weak states, which is based on the opposition and the potential - if not real - competition between civil society and the state. Curiously, the neoliberal version of the economy requires a strong civil society, demanding the withdrawal of the state to avoid its harmful effects on private initiatives. Nonetheless, civil society not only pursues economic goals, but also advances social and political objectives. This in fact requires and uses the state as a mirror of civil society, establishing a direct proportion between them: a strong state is seen as a condition sine qua non for a strong 
civil society (Sousa Santos, 2002). Thus, both versions of the state (enemy and mirror) are coexisting in our daily lives.

Within the European integration process, this dimension becomes more complex, as the construction of the European project has recurrently marginalised civil society. Thus, although in theory European civil society is well organised and has all the democratic tools to economically and politically participate in the decision-making process, the fact is that the transfer of regulative and decision-making powers to the European level has clearly made participation harder for citizens. Moreover, austerity measures have also accelerated the neoliberal nature of European economic integration, contributing to the erosion of the fundamental socio-economic conditions for participation of citizens, especially those who are and/or become more vulnerable.

In order to favour the image of the state as an enemy for economic purposes, the idea of a weak state comes with a liberal version of democracy. In this version of democracy, free elections and free markets are sides of the same coin, implying the subordination of the political sphere to economic profit, embodied by a part of civil society. A careful analysis reveals an abbreviated version of this model, which can be called a 'low intensity democracy' or a 'dimed democracy' (Sousa Santos, 2004, 2005, 2007), becoming more visible in the context of the EU. Among the features listed to describe how such an appearance of democracy is built, one is central to our argument: the idea of 'citizenship without citizens'.

In ancient Athens, about year 560 b. C., the tyrant Pisistratus said to the citizens of Athens: 'take care of your own issues, your personal concerns (idia), while I will take care of common concerns (koina). This comprehension of the political relationship presupposes that citizens are then no more citizens, in the republican sense of the term; they are turned into servants unable to take care of common issues because they are busy solving personal/private concerns and delegate power issues 'in good hands'. In fact, this means that a group (or organisation) is able to appropriate what is common, reducing others to the condition of 'idiots' (people taking care of private concerns and issues). This has an important advantage: once the public space is monopolised, interests of a certain group or groups can be considered to be common interests. By renouncing to take care of common issues, citizens opened the way for limiting their rights. Rights that in fact have lost their meaning as the material conditions required to their exercise have disappeared. So we can assess civic and supposedly political rights as being unsupported by economic, social and cultural rights. The terms and conditions of the social contract have changed by the way of facts.

A complicated system based on the hegemonic rationality of neoliberal economy is present in the EU and its politics. As Francisco Rodríguez Ortiz (2012) has pointed out when analysing the course of the present economic crisis, combining economic as well as political considerations, it is not possible to measure the damages caused by liberal politics when focused on defending the interest of national and international creditors. Today's European construction limits the scope of choices possible in national elections without providing the means for the emergence of a democratic political power at the European level (the management of the Greek debt crisis by the EU institutions illustrates the entrapment of unbalanced European norms, as well as the power imbalances created within the intergovernmental institutions of the Union). The EU is thus reducing the role of the nation-state to a mere regulator of the economy (mainly decided in Brussels, away 
from domestic constituencies) and establishing non-democratic institutions which are effectively governing away from the citizens and even against the expressed citizens' will (Rodriguez Ortiz, 2013).

Thus, nation-states' politics seems to be limited to competition: it designs strategies to impose more or less private interests against state institutions and thus not taking care of common interests (Habermas, 2005). Under this model, citizens are bearers of subjective rights under the protection of the state. They pursue their own private interests within the limits established by law and enjoy rights against the state and other citizens. These subjective rights are negative rights: they are a shield protecting one's space to choose and to act free from coercion. Political and civic rights follow this pattern: they give citizens the possibility to stand up for their own private interests and to align them to other private interests in order to institute a political will able to exercise an effective influence over the state administration. It is obvious that under such relations between rights and the state, economic, social and cultural rights have no sense and can be considered as a threat: they claim for state intervention constraining options and reducing individuals' field of initiative.

Remarkably, on December 10, 1949, the Universal Declaration of Human Rights was approved and it included, in article 28, an imperative regarding the suitable social order to fulfil human rights: 'Everyone is entitled to a social and international order in which the rights and freedoms set forth in this Declaration can be fully realized'. Following this article, all human rights must be understood as a sort of regulative idea for social construction: they are requirements to be fulfilled by and in every human society. In consequence, they set the frame to understand citizenship precisely as co-citizenship and therefore, they open the way to comprehend society as a collective project, built by all of its members and requiring the active and full participation all of them.

Adopting this perspective, a change of the current exercise of citizenship is required. The first step is to transform citizens from 'idiots' into equally free, responsible and participative citizens, who also bear in mind a collective perspective. This claims for a state that takes care of economic, cultural and social rights, preventing lobbies from imposing their particular interests onto the whole society. Thus, the role of the state is to guarantee pluralism within certain limits defined by law as the result of public debate. That involves the setting of certain minimum material, political and civic conditions to be respected.

\section{Conceptualising citizenship and the state}

In order to understand how the crisis of European integration and its consequences can be addressed, it is important to conceptualise citizenship and its relation with the state as a political institution based on and committed to rights promotion and protection. Citizenship is a highly contested and disputed concept. In its narrowest definition, citizenship can be viewed as the legal relationship between the individual and the polity (Sassen, 2002, p. 278). In its broader definition, citizenship can be defined as 'the set of practices (juridical, political, economic and cultural), which define a person as a competent member of society, and which as a consequence shape the flow of resources to persons and social groups' (Turner, 1993, p. 2). In a somehow different definition, as proposed by Janoski (1998), citizenship is 'passive and active membership of individuals in a nation-state with certain universalistic rights and obligations at a specified level of equality'. Within this definition, 
citizenship is located inside the borders of the nation-state, and though civil society is crucial in building citizenship, the nation-state remains the fundamental political reference in its definition. The citizen is a member of the national community of citizens, within which principles of equality and universality in the rule of law are established (Borges, 2013). Mapping modern citizenship thus entails a reflection on the relation between citizenship and the state, especially because it was through the process of territorial bordering that states and citizens established their existence as such.

The various understandings of citizenship have been summarised by Sassen (2002, p. 280) and Bosniak (2000) in four main images: citizenship as a legal status; as possession of rights; as political activity; and as a form of collective identity. In the first image, citizenship provides membership to individuals in a political community and assures them the legal protection of certain rights (Bosniak, 2000). Although the recognition of a legal status necessarily implies the establishment of certain rights to citizens, its main concern is the inscription of rights in a legal frame and not necessarily the required conditions for their enactment (Borges, 2013). T. H. Marshall (1992) elaborated this understanding of citizenship as rights, assuming that civil and political rights were insufficient to achieve the promised equality and that economic and social rights were also needed to materialise equality.

As affirmed by Borges (2013, p. 142),

citizenship as the right to have rights, using the arendtian precept, entails more than a recognition of a legal status and demands the effective protection, enforcement and enactment of recognised legal rights. This notion of citizenship as (effective) rights has led to a growing consciousness over excluding realities primarily related to the detachment between a legal status and the effective exercise and enjoyment of citizenship rights.

To some extent, the relationship between citizenship and rights is an illustration of the dilemmas posed to the politics of human rights, for two main reasons. First, citizenship entails a connection between the individual and its nation-state, through which rights and obligations are fulfilled. The second reason is that citizenship is no longer limited to the national dimension, and has acquired universalistic features in its conceptualisation, and transnational ones in its practices. Despite the fact that European citizenship adds to the national ones, the relation between the state and the European level rests on the principle of subsidiarity, maintaining a tension in the conceptualisation of citizenship in the EU, and in its practices. It is thus fundamental to understand the role of the European Union in shaping its member states' ability to regulate, to represent citizens' interests and to establish links to civil society. The image of the European Union as a 'regulatory state' (Sbragia, 1994) reflects the neoliberal tenets of sovereignty, impacting the national units and relations with citizens both at the European and state level.

The second image (citizenship as possession of rights) is relevant for the discussion on equality, since we need to address the practical dimension of rights. Because equality is recognised as a central feature of modern views of citizenship, the relation between civil, political, economic and social rights, which are the traditional components of a welfare state, is fundamental. When fully developed, it embodies an idea of social justice: everyone is to enjoy entitlements, which stand apart from and to some extent conflict with the outcomes of a market driven society by considerations of efficiency (Lehning, 1999, p. 5). The concerns with the welfare state, visible in the early years of European 
integration, sought to promote all citizens as equal in their national societies, as well as in a broader European society, reinforcing this through a transnational regional dimension. Thus, the political and economic choices driving the EU since the mid-1970s, with a clear neoliberal dimension, pose important challenges to equality and the fulfilment of citizenship rights. Variations in economic performance among EU member states have affected employment and living standards disproportionally, in a context where macroeconomic policies are not fully integrated. EU Competition policy has also pushed forward liberalisation in many economic sectors, including in public services, which had become a fundamental part of the European welfare-system in the post-War years (Hermann 2007, p. 13).

The third image refers to citizenship as a political activity outside of which the enjoyment of rights and an inclusive society are not possible. This view of citizenship promises solidarity that is based not on a cultural matrix but rather on a democratic political process through which individuals can be included in, and actively participate of the governance processes that affect them. In order to participate in the political life of the community other rights are needed, including access to education, health or freedom of speech. This interdependent and indivisible nature of rights, gives citizenship a comprehensive nature. Therefore, citizenship assumes that state institutions formally and de facto provide individuals with equal opportunities to exercise their citizenship, especially in liberal democratic settings. In the European context, many of these fundamental social, economic and cultural rights are still premised in the national level, as these areas have remained outside EU direct control. However, the indirect impacts of EU policies in these sectors became particularly visible during the financial crisis of 2008, with the imposition of austerity measures on EU countries risking default of their national debts. The imposed measures in Greece, Portugal and Ireland had profoundly negative social and economic impacts (European Parliament, 2015; UNDP, 2014), resulting in public demonstrations and violence in some cases.

Finally, and according to Lehning (1999), the fourth image of citizenship as identity, suggests that it must be experienced in a geographical context, regardless of how this geographical context is defined. In line with Marshall's conceptualisation of citizenship as a shared identity $(1964$, p. 78$)$ that would integrate previously excluded groups, it is here viewed as an expression of one's membership in a political community. Following this debate, Kymlicka and Norman (1995, p. 283) suggest that

if citizenship has to do with rights and identity, then clearly two dimensions are involved: a 'liberal' one and a 'communitarian' one. Citizenship is intimately linked to the ideas of individual entitlement on the one hand and of attachment to a particular community on the other.

In fact, over the years, debates over citizenship have been divided along liberal and communitarian sectors that sought to bring back the significance of belonging, to political thinking, thus carrying important consequences for citizenship. This, however, did not challenge or question the value of equality as the core of modern citizenship. In fact, liberals assumed this universal condition and the equal status of citizenship as an assurance of individuals' freedom to pursue their vision of good, though guided by a frame of rights and justice. Communitarian views approached equality and universalism as guarantees of communities' cohesion and definition through recognition as equals by its members (Borges, 2013, p. 99). 
In sum, the idea of modern citizenship departs from a western-based approach to political reality, framed by modern assumptions of the state and the central role it played in defining citizenship. This role has been affected by the dynamics of globalisation and the complex economic, political and social phenomena, which it brought along. In fact, the global reach of economic activities and political actions and decisions, and worldwide flows of people, goods and capital may be seen as mere elements of our lives but they have decisively impacted understandings of citizenship (Magnette, 2005). As Habermas (1995) advanced, not only international flows of people and migration patterns pressured a system of rights and obligations originated under the national premises of citizenship, it has also contributed to processes of identity fragmentation, challenging the unity and centrality of the nation-state for these purposes.

\section{Citizenship in the context of European integration}

Faced with an increasingly delocalised economy, growing flows of people, the emergence of global activism and human rights rhetoric and the development of global or regional governance arrangements like the EU, the state has seen its traditional monopolies and sovereignty questioned and necessarily redrawn (Burchill \& Linklater, 1996; Held \& MacGrew, 2003; Sorensen, 2006 apud Borges, 2013). This process challenges the dominant and modern view of citizenship, which cannot be separated from the space of governance it refers to - the state. Indeed, and as argued by Migdal (2001), the liberal approach to the state assumes a constitutive relation based on the identification between the state and society, where the state is recognised as the governing agent and individuals are viewed as subjects of rights and part of the political community represented by the state. This leads to the view of state and citizenship as inseparable concepts, mediated by representative democracy that allows individuals' rights and participation in society (Migdal, 2001). Citizenship appears to be necessarily linked to the formation of modern states just as states are tied to citizenship: states become membership associations, demanding the identification of individuals as members of the political community, providing the state with its social foundations. Thus, state's actions on citizenship will necessarily affect its legitimacy and, as consequence, citizenship becomes not only a constituting subject of the state but also a crucial object of its activity (Stewart, 2001). In this sense, and as affirmed by Beiner (2003), states and citizenship are mutually constitutive: citizens can only be free in a republican state and the state can only exist as the expression of popular will and be legitimised by popular sovereignty.

However, even if most definitions and conceptualisations of citizenship in its modern form focus on its relation and dependence to the nation-state, there are also different views suggesting other spaces for citizenship to be exercised. Sommers (2008, p. 20), for example, considers citizenship as the result of a 'triadic assemblage of shifting institutional and discursive relationships and struggles for power among state, market and civil society'. Globalisation has also strengthened demands for transnational frames of governance and citizenship, leading to the identification of other actors and levels of governance in the assurance, recognition and claim-making of citizenship rights.

The contributions that engage in discussing citizenship beyond the nation-state force us to reflect on the plurality of spaces where individuals and groups move and how these spaces question exclusive membership. The EU is a case in point, affecting the experience 
of citizenship-state relations. According to Bauböck and Guiraudon (2009), the EU has been, in this new scenario, a 'laboratory' where a plethora of issues, ranging from supranational integration to the territorial dimension of citizenship have been (re)defined allowing us to approach the EU as some sort of a second sphere of rights protection, enforcement and claim-making. Citizenship in the context of the EU is a multilevel concept, where the attribution of rights based on citizenship depends on nationality. Thus EU member states are the fundamental source of rights, as only their nationals are entitled to citizenship, then complemented by European citizenship - another layer of citizenship rights - added in the Maastricht Treaty, in 1992. Reflecting this double link between citizens and the national and European political orders, Wiener (1997) has referred to citizenship in Europe as 'fragmented'. The question we pose is how can we link the debates about European citizenship to the exercise of democratic rights of participation and accountability in the national and European contexts? The aim is again to understand to what extent European integration has affected the relations between the practices of citizenship and the ability of the state to fulfil citizens' rights.

The political debate on the establishment of a European citizenship emerged more prominently in the 1970s, linked to concerns with the perceived lack of democratic legitimacy of the Communities among European citizens. However, as early as 1957, under the Rome Treaty, specific individual rights were established and later upheld by the European Court of Justice (ECJ), which can be considered as embryonic of European citizenship rights (Jacobs, 2007, pp. 592-593). Among these, freedoms of movement, as well as the rights of workers across the Communities, were particularly important to establish a sense of belonging and uniform protection, regardless of nationality. ${ }^{1}$ This socio-economic dimension of rights was complemented by the debates of the 1970s, which introduced a more political dimension to citizenship issues at the European level, responding to the perceived democratic deficit of the Communities. The tension between the two dimensions came to shape the understanding of the European citizenship developed in Maastricht.

Academic work on the democratic deficit of the European Union underlines two important dimensions: legitimacy of European institutions and policies derived from a positive perception of the outputs of European integration by the citizens; or legitimacy derived from the inputs to the European political process. The inputs include greater citizen participation, namely electing European representatives, and greater accountability of European politics and institutions vis-à-vis the citizens. ${ }^{2}$ Both dimensions are directly relevant to how European citizenship was conceptualised. The 1970s were known as the 'Euro-sclerosis' years, with significant deceleration of European integration and economic setbacks in most EC economies. This raised issues among citizens about the legitimacy of the European project derived exclusively from the positive outputs in economic and social terms. Responding to the situation European leaders decided to reinforce legitimacy through input, namely establishing the right of citizens to elect the European Parliament (EP) in direct elections, and reinforcing the EP's oversight powers. This process was supported by reflections within the European institutions on a European identity and the establishment of a (political) European Union. ${ }^{3}$

Considering this context, the preparations for the Maastricht Treaty engaged with the issue of establishing a European citizenship, which would complement and derive directly from the national ones. In the preamble of the Treaty, the Heads of State committed themselves 'to establish a citizenship common to nationals of their countries'. The Treaty thus 
contained a Part Two, comprised of six articles, dedicated to the 'Citizenship of the Union'. This part established four fundamental rights: (a) the right to move freely and reside in any country of the EU; ( the right to stand for local elections and in elections for the EP in the country of residence, of which they are not nationals; (c) the right to diplomatic and consular protection by another EU member state; (d) and the right of petition to the EP and the EU Ombudsman. These rights are mainly political ones and left out of the debate the more social and economic dimension of European citizenship, which the Rome Treaty initially conceived (Martiniello, 1994). This was in line with the neoliberal approach to European economics taking over in the late 1970s and 1980s.

The Amsterdam and Nice Treaties did not make significant changes to these conceptualisations of citizenship at the European level. Although the Amsterdam Treaty dedicated a chapter to Employment, EU institutions were not given powers to impose quotas or certain policies on member states, but rather focused on the need for consultation and cooperation, in order to achieve agreed goals (Faist, 2001). The Treaty did however refer to the foundations of the EU being linked to protection and advancement of fundamental human and particularly social rights, as defined in the European Convention on Human Rights (1950), the European Social Charter (1961) and developed in the EU's Charter of Social Rights (1989), linking European citizenship to the protection of these rights. This concern with social rights, expressed in these fundamental texts, was meant to act as a counterbalance to the Union's neoliberal policies, gradually taking place since Maastricht in preparation for the establishment of the Economic and Monetary Union (EMU). As has become quite visible, the balance of forces between the liberalising impulse and the social concerns has been lost in favour of the former thus directly and indirectly affecting the capacity to attain the aspirations of full European citizenship.

Under the Lisbon Treaty, adopted in 2009 by all EU member states, many of the concerns with the democratic deficit of the EU expressed in the Convention on the Future of Europe were addressed. The Charter of Fundamental Rights and the EU's Charter of Social Rights were fully incorporated in the Treaty, reinforcing its ability to shape EU institutions' and its member states' actions. Overall, they seek to reinforce the EU's social policy in articulation with important instruments such as the Open Method of Coordination and the Lisbon Strategy (Daly, 2008). The Lisbon Treaty also reinforces issues of transparency and accountability of the EU institutions as a way to bring citizens closer to the Union. This is achieved namely by making advocacy and lobbying by civil society organisations better structured in the EU.

\section{The European Citizenship Initiative and citizen rights}

The practice of European citizenship is a fundamental part of the Union's entrenchment and vitality, despite the fact that active participation of citizens in the Union's decisionmaking remains fairly limited. The problem is that most citizens view their citizenship rights at EU level as being limited to voting in elections for the EP every five years and consider policy action at the EU level distant and difficult. Nevertheless, and under the Lisbon Treaty, some important steps have been taken such as the launching of the European Citizens' Initiative (ECl) in April 2012. This Initiative sought to promote a more active participation of citizens, allowing individuals to use transnational coalitions to shape EU policies reflecting the liberalisation moves. The $\mathrm{ECl}$ thus capacitates citizens who are nationals of 
Member States to call directly on the European Commission to adopt and bring forward legislative proposals in an area of EU competence and which affects the civil, political, social and economic rights of European citizens. ${ }^{4}$ To some extent, we can consider the $\mathrm{ECl}$ as an important tool for participatory democracy within the EU, since it entails and enables citizens to play a more active role in European political processes. Ever since its launching, around 6 million European citizens have been involved in these processes rendering clear the increasing interest and importance that active participation in the affairs affecting citizenship has for European citizens.

According to Greenwood (2012), the $\mathrm{ECl}$ is

clearly distinguishable from the mainstream constituency of Brussels based interest groups geared towards institutionalized dialogue between themselves and EU institutions. Stressing this distinction, European Parliament Vice-President Diana Wallis, the EP's member most involved with institutional measures for participatory democracy affecting both direct and organised civil society strands, commented forthrightly: 'an ECl is not for MEPs, not for NGOs, but for all citizens (Greenwood, 2012, p. 2).

Furthermore, the community that it has constituted is 'founded on organizations mobilized around direct democracy measures, and in particular the 2009 'European Citizens Consultations' experiments initiated by Commissioner Wallstrom (Greenwood, 2012, p. 4).

From the many ECls that were organised in the past five years, ranging from employment to education, transports, circulation within the EU and other areas, only three were successful: 'Stop Vivisection'5, 'One of Us' ${ }^{6}$ and 'Water and sanitation are a human right! Water is a public good, not a commodity!" Through the $\mathrm{ECl}$ on the Human Right to Water, citizens pushed for EU legislation requiring governments to ensure and provide everyone with sufficient and clean drinking water and sanitation. Specifically, it called for

1. The EU institutions and Member States [to] be obliged to ensure that all inhabitants enjoy the right to water and sanitation. 2. Water supply and management of water resources not [to] be subject to 'internal market rules' and that water services [be] excluded from liberalisation. 3. The EU [to] increase[...] its efforts to achieve universal access to water and sanitation. (right2water.eu)

This Initiative is of particular relevance for our analysis since it expresses well the importance of having spaces for the practice of citizenship rights in particular at the European level. The focus here is clearly on the potentially negative/perverse impacts liberalisation policies and trends at the European level may have on the protection, enjoyment and fulfilment of citizen's rights. In the case of the water sector, European policies have also been responding to the liberalisation dynamics, and access to water in many European countries has suffered a marketisation process, meaning both private sector participation and commodification of water services (Gleick et al. 2002; Lopes, 2008).

The recognition of a Universal Human Right to water by the United Nations provided the basis for citizens' mobilisation under this initiative, demanding that the EU establish measures to implement this right. This provides an interesting illustration of how a transnational understanding of rights needs to be linked to the national and individual level. In the case of the European Union, the effective implementation of such a right would require that EU institutions be bound by this normative framework, preventing EU legislation from hindering the fulfilment of the right to water. Despite the fact that EU 
member states are the ultimate responsible entities for the respect, fulfilment and protection of citizen rights, the multilevel nature of EU governance requires alignment also on these issues. Thus, this initiative displays the potential for multilevel citizenship, harnessing the potential for transnational mobilisation, seeking to limit the negative impacts of deregulation, liberalisation and marketisation. Nevertheless, previous studies indicate that successful mobilisation may rest on the ability of issue-based semi-professionalised civil society organisations to mobilise public opinion (De Clerck-Sachsse, 2012). Nevertheless, and as argued by Agustín (2014), the Right to Water initiative

[...] exemplified how citizens foster a discourse on the commons (...) opposed to the current tendency of privatization of water services and more generally, by declaring water as a human right, as opposed to the market-oriented approach to public services sustained by the EU. The $\mathrm{ECl}$ places the space of the deliberation in the EU institutions where the activists who promoted the $\mathrm{ECl}$ (and not actors previously selected by the Commission) can present their arguments in a public hearing

Although the $\mathrm{ECl}$ is often considered as just an agenda-setting tool (Agustín, 2014; Greenwood, 2012), since it has no mandatory force, the various initiatives proposed and/or in preparation tend to show how the $\mathrm{ECl}$ is 'mobilizing a diverse number of constituencies separate from traditional EU NGOs'. As examples, we can refer to the initiatives promoted by an Austrian NGO linked to the 'Occupy movement' which is preparing a measure on basic income protection; or the one being organised by internet activists who are mobilising against anti-piracy laws (Brand, 2012 apud Greenwood, 2012, p. 15). Clearly, the involvement of civil society and citizens' active participation thus becomes a crucial goal and one of the principles of good governance within the EU (Agustín, 2014). In sum, all these initiatives demonstrate how European citizenship can actually be enacted and reinforced through and promoted by the European institutions themselves, while at the same time providing a potentially effective remedy for the democratic deficit of the EU by enabling EU citizens to become directly involved in the policy-making process (Agustín, 2014; Teglas, 2012, p. 21) and thus calling upon member-states to be aware of their responsibilities in terms of their citizen's protection.

\section{Conclusions: the state, citizens and the path ahead for Europe}

This reflection on the role of the state and its responsibilities towards citizens, particularly within the European Union, is closely linked to the contemporary role of institutions and relations between the state and its citizens. As the nature of challenges to fundamental rights grows more global (economic crisis, migrations, etc.) and as its consequences become visible at the local and individual level; what role is there left for the state, particularly when it comes to guaranteeing citizenship and rights? The view of rights as being exclusively attributed to individuals by a political authority has been extensively criticised for removing the capacity of agency from disenfranchised populations as well as for undermining democracy. The ability to actively contest the meaning of rights, its content, and its practical application is a fundamental condition to exercise autonomy and power, turning human rights subjects into human rights agents. Active and participative forms of rights, civil and political as well as economic, social and cultural, can only be achieved if we address and overcome the contradictions inherent to the very meaning of 
human rights norms. Namely, to promote freedom, but impose conservative rules; promote participation, but restrict active citizenship (Neocosmos, 2006, p. 358). Moreover, contradictions in human rights practices also need to be addressed (Hoover \& de Heredia, 2011).

Democratic states and institutions should fulfil four basic requirements: respect for the rule of law; the protection of fundamental freedoms; secure property rights; and conformity to the principle of majority rule in the making of public policy (Rawls, 1971, pp. 221-243). The state, being modernity's most prominent and lasting creation, seems to stand as the ultimate homogeniser and even oppressor in this process, both in its relations with its citizens and in relations with other individuals at the global level. The reduction of citizenship to a passive activity, concentrated at the political level, but unable either to influence actively politics, or to define the outcome of socio-economic struggles, is limitative of the idea of human rights we project in our interaction with the world. The multilevel nature of these changes and challenges, their impacts, as well as the fundamental role of European integration and institutions in addressing these processes thus need to be assessed.

European integration has limited EU member states competences, in areas directly affecting human and citizenship rights, and has imposed a homogenising tendency towards neoliberalism. This trend, visible since the 1970s, has rested on deregulation, free market competition and privatisation, turning EU states into weak regulatory states, not social entities, closely sustaining economic activity and welfare structures. In the context of austerity measures, this trend became particularly acute. This paper focused on the $\mathrm{ECl}$ on the Human Right to Water, as a means to understand the potential for multilevel citizenship under European integration. Although transnational mobilisation was possible, previous research on the $\mathrm{ECl}$ suggests that semi-professionalised civil society organisations are important actors in this process. Moreover, member states' relations with EU institutions are also crucial to ensure changes in legislation and the substantive means to ensure fulfilment of this right. The failure to respond to citizens' needs and demands would prove a fatal blow to European integration and its democratic legitimacy, as well as to the relevance of the state as the primary responsible for the protection of its citizens' rights.

\section{Notes}

1. These rights were only granted to migrant workers from other members of the European Communities (EC), de facto creating a barrier between those in and those outside the EC.

2. See Follesdal and Hix (2006) and Chryssochoou (2010), among others.

3. In 1973, at the European Council in Copenhagen, the Heads of State issued a declaration on European Identity, and the Tinderman's report on the European Union was also released, both contributing to the idea of a political dimension of the European integration process, where the issue of citizenship and democratic participation had to be reinforced. In 1975, the European Commission release a report named 'Towards a European Citizenship', furthering the debate. See Martiniello (1994).

4. In case the European Commission validates the Initiative proposal it may take steps in order to adopt legislation on the topic according to the established procedures.

5. Initiative proposing an European legislative framework aimed at phasing out animal experiments. 
6. Initiative calling for the juridical protection of the dignity, the right to life and of the integrity of every human being from conception in the areas of EU competence in which such protection is of particular importance

7. Initiative inviting the European Commission to propose legislation implementing the human right to water and sanitation as recognised by the United Nations, and promoting the provision of water and sanitation as essential public services for all.

\section{Acknowledgement}

The authors would like to thank Evangelos Fanoulis for the insightful and helpful comments on the version presented at the 2015 UACES Annual conference, Bilbao, Spain. The authors would also like to acknowledge that research leading to these results has received funding from the Marie Skłodowska-Curie Innovative Training Networks (ITN-ETN) of the European Union's Horizon 2020 research and innovation programme, under grant agreement 'CASPIAN - Around the Caspian: a Doctoral Training for Future Experts in Development and Cooperation with Focus on the Caspian Region (642709 - CASPIAN - H2020-MSCA-ITN-2014).

\section{Funding}

The author would like to acknowledge the support granted by the Portuguese Science and Technology Foundation under its Strategic Project [UID/SOC/50012/2013].

\section{References}

Agustín, O. G. (2014, March 10). Mobilization and deliberation. EU for the Citizens? E-International Relations. Retrieved September 26, 2017, from http://www.e-ir.info/2014/03/10/moblization-anddeliberation-eu-for-the-citizens/

Bauböck, R., \& Guiraudon, V. (2009). Introduction: Realignments of citizenship: Reassessing rights in the age of plural memberships and multi-level governance. Citizenship Studies, 13(5), 439-450.

Beiner, R. (2003). Liberalism, nationalism, citizenship. Essays on the problem of political community. Vancouver: UBC Press.

Borges, M. (2013). Citizenship and post-armed conflict statebuilding: Re-engaging with power and politics in spaces of intervention: The illustrative case of Guatemala (PhD Dissertation). University of Coimbra.

Bosniak, L. (2000). Citizenship denationalized. Indiana Journal of Global Legal Studies, 7(2), 447-509.

Brown, W. (2010). Walled states, waning sovereignty. New York: Zone Books.

Brown, W. (2015). Undoing the demos. Neoliberalism's stealth revolution. New York: Zone Books.

Burchill, S., \& Linklater, A. (1996). Theories of international relations. New York: St. Martin's Press.

Chryssochoou, D. (2010). Europe's contested democracy. In M. Cini, \& P.-S. B. Nieves (Eds.), European union politics (pp. 377-389). Oxford: Oxford UP.

Daly, M. (2008). Whither EU social policy? An account and assessment of development in the Lisbon Social inclusion process. Journal of Social Policy, 37(1), 1-19.

De Clerck-Sachsse, J. (2012). Civil society and democracy in the EU: The paradox of the European citizens' initiative. Perspectives on European Politics and Society, 13(2), 299-311.

European Parliament. (2015). "The impact of the crisis on fundamental rights across Member States of the EU Comparative analysis", Directorate General for Internal Policies, Policy Department C: Citizens' Rights and Constitutional Affairs. Civil Liberties, Justice and Home Affairs, PE 510.021.

Faist, T. (2001). Social citizenship in the European union: Nested membership. JCMS: Journal of Common Market Studies, 39(1), 37-58.

Ferrajoli, L. (2010). Derechos y garantías. La ley del más débil. Madrid: Trotta.

Follesdal, A., \& Hix, S. (2006). Why there is a democratic deficit in the EU: A response to Majone and Moravcsik. JCMS: Journal of Common Market Studies, 44(3), 533-62. 
Gerbaudo, P. (2017). The indignant citizen: Anti-austerity movements in Southern Europe and the anti-oligarchic reclaiming of citizenship. Social Movement Studies, 16(1), 36-50.

Gleick, P., Burns, W., Chalecki, E., Cohen, M., Cushing, K. K., Mann, A. ... Wong, A. (2002). The World's Water 2002-2003: The Biennial Report on Freshwater Resources. Washington, DC: Island Press.

Greenwood, J. (2012). The European citizen's initiative and EU civil society organisations. Perspectives on European Politics and Society, 13(3), 325-336.

Habermas, J. (1995). Citizenship and national identity. Some reflections on the future of Europe. In R. Beiner (Ed.), Theorizing citizenship (pp. 255-282). Albany: State University of New York Press.

Habermas, J. (2005). Tres modelos de democracia. Sobre el concepto de una política deliberative. Polis, Revista de Louisiana Universidad Bolivariana [online] 4, 10. Retrieved 25 October, 2015, from http://www.redalyc.org/articulo.oa?id=30541007> ISSN 0717-6554

Held, D., \& McGrew, A. (Eds.). (2003). The global transformations reader. (2nd ed.) London: Polity. Hermann, C. (2007). Neoliberalism in the European Union. Studies in Political Economy, 79. Spring.

Hoover, J., \& de Heredia, M. I. (2011). Philosophers, activists, and radicals: A story of human rights and other scandals. Human Rights Review, 12(2), 191-220.

Jacobs, F. G. (2007). Citizenship of the European union-A legal analysis. European Law Journal, 13(5), 591-610.

Janoski, T. (1998). Citizenship and civil society: A framework of rights in liberal, traditional and social democratic regimes. Cambridge: Cambridge University Press.

Kohler-Koch, B. (2009). The three worlds of European civil society-what role for civil society for what kind of Europe? Policy and Society, 28(1), 47-57.

Kymlicka, W., \& Norman, W. (1995). Return of the citizen: A survey of recent work on citizenship theory. In R. Beiner (Ed.), Theorizing citizenship (pp. 283-322). Albany: State University of New York Press.

Lehning, P. B. (1999). European citizenship: Towards and European identity? Working Paper Series in European Studies, $2,3$.

Lopes, P. D. (2008). Water with Borders: the Institutional Postponement of International Water Trade. In International Studies Association Annual Convention Proceedings. [February 5, 2015].

Mackert, J., \& Turner, B. S., (Eds.). (2017). The transformation of citizenship, volume 2: Boundaries of inclusion and exclusion. London: Routledge.

Magnette, P. (2005). Citizenship: The history of an idea. Colchester: ECPR Press.

Marshall, T. H. (1964). Class, citizenship and social development. New York: Doubleday.

Marshall, T. H. (1992). 'Citizenship and social class. In T. Bottomore (Ed.), Citizenship and social class (pp. 1-51). London: Pluto Press.

Martiniello, M. (1994). Citizenship of the European union: A critical view. In R. Bauböck (Ed.), From Aliens to citizens: Redefining the Status of immigrants in Europe (pp. 29-47). Avebury: Aldershot.

Migdal, J. S. (2001). State in society: Studying How states and societies transform and constitute One another. Cambridge: Cambridge University Press.

Neocosmos, M. (2006). Can a human rights culture enable emancipation? Clearing some theoretical ground for the renewal of a critical sociology. Southern African Review of Sociology, 37(2), 356-379.

Ortiz, F. R. (2012). Las máscaras de la crisis. Madrid: Libros de la Catarata.

Ortiz, F. R. (2013). Europa: Una deriva liberal que prolonga la crisis, cuestiona los principios democráticos y banaliza el mal. Papeles de Relaciones Ecosociales y Cambio Global, 123, 29-40.

Rawls, J. (1971). A theory of justice. Cambridge: Harvard University Press.

Sassen, S. (2002). Towards post-national and de-nationalized citizenship. In B. S. Turner, \& I. Engin (Eds.), Handbook of citizenship studies (pp. 277-291). London: Sage Publications.

Sassen, S. (2015). Losing control? Sovereignty in an age of globalization. New York: Columbia University Press.

Sbragia, A. M. (1994). The community as polity: The political economy of regulation. APSA-CP American Political Science Association - Comparative Politics.

Sommers, M. R. (2008). Geneologies of citizenship. Markets, statelessness and the rights to have rights. Cambridge: Cambridge University.

Sorensen, G. (2006). The transformation of the state. In H. Colin, M. Lister, \& M. David (Eds.), The state: Theories and issues (pp. 190-208). Basingstoke: Palgrave Macmillan. 
Sousa Santos, B. (2002). The processes of globalization. Eurozine, August 22. Retrieved November 25, 2015, from http://www.eurozine.com/articles/2002-08-22-santos-en.html

Sousa Santos, B. (2004). Democratizar la democracia: Los caminos de la democracia participativa. México: Fondo de Cultura Económica.

Sousa Santos, B. (2005). El milenio huérfano. Madrid: Trotta.

Sousa Santos, B. (2006). Globalizations. Theory, Culture and Society, 23(2-3), 393-399.

Sousa Santos, B. (2007). Globalización y democracia. Archipiélago, 73-74, 111-125.

Stewart, A. (2001). Theories of power and domination: The politics of empowerment in late modernity. London: Sage Publications.

Teglas, P. (2012). The European Citizens' Initiative (un)successful tool of deliberative democracy; present state and future perspectives. ECIT Foundation. Retrieved September 26, 2017, from (available at http://ecit-foundation.eu/wpcontent/uploads/2015/11/Peter_Tegas_The_European_ Citizens_Initiative_2015.pdf

Turner, B. S. (1993). Citizenship and social theory. London: Sage Publications.

UNDP. (2014). Human development report 2014. Sustaining human progress: Reducing vulnerabilities and building resilience. New York: United Nations Development Programe.

Wiener, A. (1997). Making sense of the new geography of citizenship: Fragmented citizenship in the European union. Theory and Society, 26(4), 529-560. 
Copyright of European Politics \& Society is the property of Routledge and its content may not be copied or emailed to multiple sites or posted to a listserv without the copyright holder's express written permission. However, users may print, download, or email articles for individual use. 